\title{
EFFECT OF INCREASING ZEARALENONE LEVELS ON THE TECHNOLOGICALLY PROBLEMATIC MICROORGANISMS AND FOOD RISKY PATHOGENS (IN VITRO)
}

\author{
Ludmila Křížová1, Marcela Klimešová², Oto Hanuš², Irena Němečková2, \\ Petr Roubal², Jana Tšponová1, Miroslav Skřivánek², Ludmila Nejeschlebová \\ Radoslava Jedelská2

\begin{abstract}
${ }^{1}$ Department of Animal Breeding, Animal Nutrition and Biochemistry, Faculty of Veterinary Hygiene and Ecology, University of Veterinary and Pharmaceutical Sciences Brno, Palackého tř. 1946/1, 61242 Brno, Czech Republic

2 Dairy Research Institute Ltd., Ke Dvoru 12a, 16000 Prague, Czech Republic
\end{abstract}

Link to this article: https://doi.org/10.11118/actaun.2021.010

Received: 15. 9. 2020, Accepted: 5. 1. 2021

To cite this article: KŘÍŽOVÁ LUDMILA, KLIMEŠOVÁ MARCELA, HANUŠ OTO, NĚMEČKOVÁ IRENA, ROUBAL PETR, TŠPONOVÁ JANA, SKŘIVÁNEK MIROSLAV, NEJESCHLEBOVÁ LUDMILA, JEDELSKÁ RADOSLAVA. 2021. Effect of Increasing Zearalenone Levels on the Technologically Problematic Microorganisms and Food Risky Pathogens (in Vitro). Acta Universitatis Agriculturae et Silviculturae Mendelianae Brunensis, 69(1): 91-100.

\begin{abstract}
The aim of this study was to determine the effect of different zearalenone (ZEA) concentrations $(0,10,100,250,500,1000 \mu \mathrm{g} / \mathrm{l})$ on growth of Bacillus cereus, Staphylococcus aureus and Pseudomonas fluorescens in milk. The samples were incubated for 6 days at 22 and $30^{\circ} \mathrm{C}(\mathrm{B}$. cereus and S. aureus) or at 6.5 and $22^{\circ} \mathrm{C}$ (P. fluorescens), respectively. Counts of bacteria in milk were measured every 24 hours. Maximum counts of $B$. cereus after $144 \mathrm{~h}$ of incubation at $30^{\circ} \mathrm{C}$ ranged from 7.00 to $7.78 \mathrm{log}$ $\mathrm{CFU} / \mathrm{ml}$. The most significant effect of ZEA on $B$. cereus across the experiment was observed after $96 \mathrm{~h}$ of incubation at $22^{\circ} \mathrm{C}$ and after $72 \mathrm{~h}$ at $30^{\circ} \mathrm{C}(P<0.001$ and $P<0.01$, respectively). S. aureus maintained at $30^{\circ} \mathrm{C}$ showed similar growth parameters as at $22^{\circ} \mathrm{C}$ regardless of ZEA presence. The most significant effects of ZEA on S. aureus were after $120 \mathrm{~h}$ of incubation at $22^{\circ} \mathrm{C}$ and after $72 \mathrm{~h}$ at $30{ }^{\circ} \mathrm{C}(P<0.001)$. The growth of $P$. fluorescence at $6.5^{\circ} \mathrm{C}$ was slower compared to growth at $22^{\circ} \mathrm{C}$. The most significant effect of ZEA between ZEA spiked and Z0 samples on $P$. fluorescence across the experiment was observed after 48 hours of incubation at $22^{\circ} \mathrm{C}(P<0.001)$.
\end{abstract}

Keywords: mycotoxin, milk, viability, Bacillus cereus, Staphylococcus aureus, Pseudomonas fluorescens

\section{INTRODUCTION}

Because milk and dairy products are significant components of human diet great emphasis is placed on their safety. Although the sources of milk contamination are multiple, microbiological hazards are a major food safety concern in the dairy sector. Microbes that may be present in milk can include not only conditionally beneficial microorganisms such as lactic acid bacteria but also microorganisms linked to detrimental effects on human health (pathogens) or product quality (spoilage microorganisms) (Boor et al., 2017).

As a foodborne pathogen Staphylococcus aureus (S. aureus, Gram-positive coccal bacterium) is responsible for a variety of health problems and diseases related to food consumption (Jamali et al., 2015). S. aureus belongs to the most frequent microbial contaminant of raw milk and its occurrence depends on the type of milk and geographical origin (Valík et al., 2018). Its prevalence in bovine milk ranges from 47 to 75\% (Jørgensen et al., 2005; Mehli et al., 2017). 
Bacillus cereus (B. cereus, Gram-positive aerobic spore-forming bacterium) is one of the most significant spoilage microorganisms found in milk and dairy products (Vyletělová et al., 2000) because the spores are heat-resistant and can survive thermal treatments of milk, grow during storage temperatures (Páčová et al., 2003) and germinate rapidly upon heat activation (Noriega et al., 2003). As a producer of various extracellular enzymes B.cereus can be responsible for spoilage and decreased organoleptic quality of milk (Kumari and Sarkar, 2016). Furthermore, it may also cause foodborne diseases due to the production of toxins (Andersson et al., 1995).

Pseudomonas spp., particularly Pseudomonas fluorescens (P. fluorescens, Gram-negative psychrotrophic bacteria) are the most commonly isolated bacteria from raw milk (Vyletělová and Hanuš, 2000) with a significant spoilage potential due to production of lipolytic and proteolytic enzymes during the storage at lower temperatures, which decreases quality and shelf life of milk and dairy products (Vyletělová et al., 2000). Moreover, $P$. fluorescens is highly heterogeneous species and includes virulent and sub-clinical strains that are involved in opportunistic nosocomial infections (Rossignol et al., 2009).

The other possible way of raw milk contamination is via dietary mycotoxins with proved carry-over from feed into milk (Becker-Algeri et al., 2016; Flores-Flores et al., 2015). Zearalenone (ZEA) is one of the main mycotoxin contaminants of dairy diets based on maize silages (Becker-Algeri et al., 2016) and recently its occurrence in milk and dairy products was reported as summarised in our previous study (Hanuš et al., 2018). Except of health effects on human and animals, such as estrogenic activity, hepatotoxicity, hematotoxicity or imunotoxicity (Tinyiro et al., 2011), effects of ZEA on growth and viability of cells were reported (Zhang et al., 2020; Hanuš et al., 2018; Zheng et al., 2018). However, the interaction between ZEA and above mentioned milk pathogens and spoilage bacteria was not studied. Thus, the aim of the study was to evaluate the effect of increasing levels of ZEA on growth of selected contaminant microorganisms including pathogenic at different temperatures.

\section{MATERIALS AND METHODS}

\section{Selection and Preparation of Strains}

A strain of B. cereus (26 B, own collection; isolated from raw cow milk) and a reference strain of $S$. aureus (Czech Collection of Microorganisms, Masaryk University, Brno; CCM 6188) were multiplied in a broth (10 g Pepton, $10 \mathrm{~g}$ Lab Lemco Poder, $5 \mathrm{~g} \mathrm{NaCl}$, $1000 \mathrm{ml}$ distilled water) at $36^{\circ} \mathrm{C}$ for $24 \mathrm{~h}$. Two strains of $P$. fluorescens, ZB 66 (own collection; isolated from raw cow milk) and CCM 2826 (reference strain) were multiplied in a Pseudomonas broth containing 1\% of glycerol and $0.1 \%$ of milk powder (Merck) at $30^{\circ} \mathrm{C}$ for $24 \mathrm{~h}$. Then the counts of bacteria (CFU/ml) were determined (ČSN EN ISO 7218, 2008).

\section{Preparation, Inoculation and Incubation of Milk Samples}

As an experimental medium the UHT milk (1.5\% of fat) was chosen. Prior the experiment counts of mesophilic and spore-forming bacteria were determined with negative results. The $100 \mathrm{ml}$ samples were inoculated with multiplied cultures of $B$. cereus and $S$. aureus. Starting counts of $B$. cereus were 75 and $72 \mathrm{CFU} / \mathrm{ml}$ for temperature of $22^{\circ} \mathrm{C}$ and $67 \mathrm{CFU} / \mathrm{ml}$ for temperature of $30^{\circ} \mathrm{C}$. Counts of $S$. aureus were 86 and $142 \mathrm{CFU} / \mathrm{ml}$ for $22^{\circ} \mathrm{C}$ and $86 \mathrm{CFU} / \mathrm{ml}$ for $30^{\circ} \mathrm{C}$, respectively. Starting concentrations of $P$. fluorescens were $480 \mathrm{CFU} / \mathrm{ml}$ (strain $\mathrm{ZB} \mathrm{66)}$ and $585 \mathrm{CFU} / \mathrm{ml}$ (strain CCM 2826) for both temperatures of $22^{\circ} \mathrm{C}$ and $6.5^{\circ} \mathrm{C}$. Individual milk samples were spiked with ZEA (purity min. 98\%, purchased from Sigma-Aldrich, Germany) solution diluted in ethanol (Hanuš et al., 2018) to reach the concentrations of $10,100,250,500$ and $1000 \mu \mathrm{g} / \mathrm{l}$, it is groups Z10, Z100, Z250, Z500 and Z1000, respectively. Two controls were used in the experiment:

1. control growth of microorganisms without ZEA and ethanol (C);

2. control growth of microorganisms with ethanol and without ZEA (Z0).

Samples were cultivated for 6 days and sampled after 24, 48, 72, 96, 120 and $144 \mathrm{~h}$ of incubations according to the applicable standard for the cultivation of given micro-organism, (B. cereus) (ČSN ISO 7932, 1995), (S. aureus) (ČSN EN ISO 6888-1, 1999) and (P. fluorescens) (ČSN ISO 8552, 2005). The results of $B$. cereus and $S$. aureus were expressed as the average of four measurements for each species while results of $P$. fluorescens were expressed as the average of four values (2 values of $P$. fluorescens ZB 66 and 2 values of P. fluorescens CCM 2826) (ČSN EN ISO 7218, 2008).

\section{Calculations and Statistics}

The obtained microbiological values were transformed logarithmically for better comparison of growth curves among the tested microorganisms (Hanuš et al., 2011). The basic statistical characteristics were calculated using the Microsoft Office Excel 2003 (Redmond, Washington, USA). A paired t-test was performed to demonstrate the significance of the differences in results between the selected segments of the growth curves of the microorganisms without influence and under the influence of the ZEA addition.

\section{RESULTS}

\section{Bacillus cereus}

The growth curves of $B$. cereus are shown in Fig. 1 to 3. From these values it is evident no reduction in growth of $B$. cereus during $144 \mathrm{~h}$ of 
incubation at both 22 and $30^{\circ} \mathrm{C}$ even when high concentrations of ZEA were used. In general, the counts of $B$. cereus were rising sharply and reached cca $8 \log \mathrm{CFU} / \mathrm{ml}$ within $48 \mathrm{~h}$ of incubation regardless of initial inoculation level, cultivation temperature or ZEA concentration. At the end of incubation at $22^{\circ} \mathrm{C}$, the total bacterial counts ranged from 7.00 to $7.85 \log \mathrm{CFU} / \mathrm{ml}$ (initial inoculation of $75 \mathrm{CFU} / \mathrm{ml})$. Similar counts of B. cereus ranging from $7.30 \log \mathrm{CFU} / \mathrm{ml}$ (Z500) to $7.90 \log \mathrm{CFU} / \mathrm{ml}$ (Z100) were observed also in a case of initial inoculation of $72 \mathrm{CFU} / \mathrm{ml}$. After $144 \mathrm{~h}$ of incubation at $30^{\circ} \mathrm{C}$, the

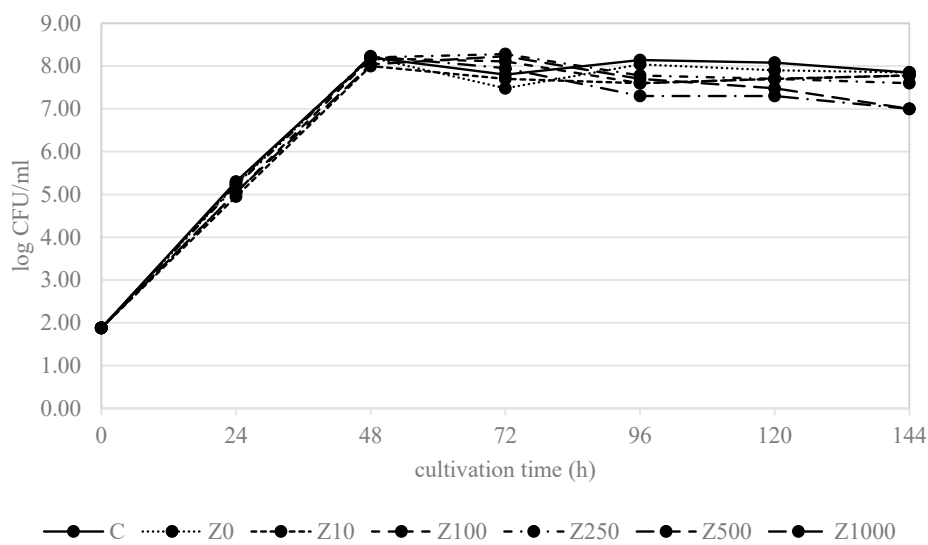

1: Growth curves of Bacillus cereus (inoculated at $75 \mathrm{CFU} / \mathrm{ml}$ ) in zearalenone-spiked milk at $22^{\circ} \mathrm{C}$

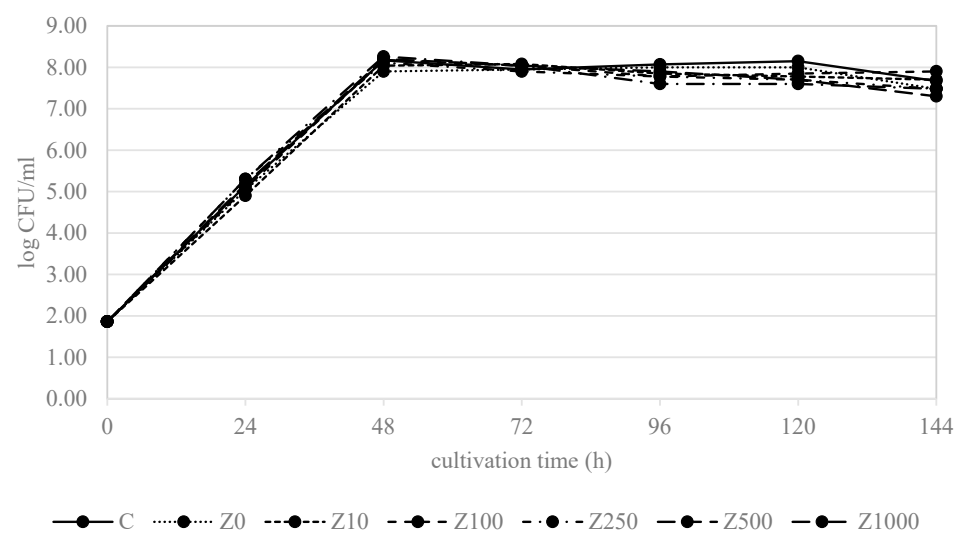

2: Growth curves of Bacillus cereus (inoculated at $72 \mathrm{CFU} / \mathrm{ml}$ ) in zearalenone-spiked milk at $22{ }^{\circ} \mathrm{C}$

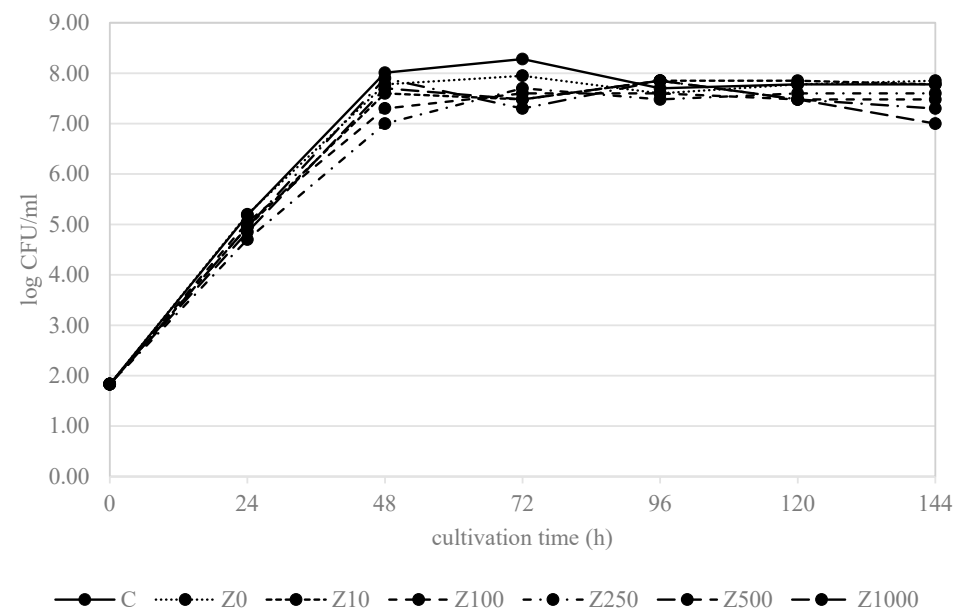

3: Growth curves of Bacillus cereus (inoculated at $67 \mathrm{CFU} / \mathrm{ml}$ ) in zearalenone-spiked milk at $30^{\circ} \mathrm{C}$ 
I: Results of differences and their significance between selected segments of the growth curves of Bacillus cereus without and with zearalenone addition $(n=5)$

\begin{tabular}{|c|c|c|c|c|c|c|c|}
\hline $\begin{array}{c}\text { Cultivation temp. } \\
\left({ }^{\circ} \mathrm{C}\right)\end{array}$ & $\begin{array}{l}\text { Cultivation time } \\
(\mathrm{h})\end{array}$ & $d \pm s d$ & $t$ & $\mathrm{P}$ & $\mathrm{d} \pm \mathrm{sd}(\log )$ & $t$ & $\mathrm{P}$ \\
\hline \multirow{6}{*}{$22^{1}$} & 24 & $0.40 \pm 0.386$ & 2.07 & ns & $0.13 \pm 0.128$ & 2.03 & ns \\
\hline & 48 & $0.20 \pm 0.309$ & 1.29 & ns & $0.07 \pm 0.103$ & 1.36 & ns \\
\hline & 72 & $-0.95 \pm 0.577$ & 3.29 & $*$ & $-0.57 \pm 0.235$ & 4.85 & ** \\
\hline & 96 & $0.68 \pm 0.148$ & 9.19 & $* * *$ & $0.44 \pm 0.182$ & 4.84 & ** \\
\hline & 120 & $0.39 \pm 0.141$ & 5.53 & $* *$ & $0.32 \pm 0.181$ & 3.54 & $*$ \\
\hline & 144 & $0.35 \pm 0.251$ & 2.79 & $*$ & $0.42 \pm 0.401$ & 2.09 & ns \\
\hline \multirow{6}{*}{$22^{2}$} & 24 & $-0.40 \pm 0.523$ & 1.53 & ns & $-0.11 \pm 0.168$ & 1.31 & ns \\
\hline & 48 & $-0.67 \pm 0.276$ & 4.86 & $* *$ & $-0.26 \pm 0.085$ & 6.12 & $* *$ \\
\hline & 72 & $-0.17 \pm 0.156$ & 2.18 & ns & $-0.07 \pm 0.069$ & 2.03 & ns \\
\hline & 96 & $0.38 \pm 0.147$ & 5.17 & $* *$ & $0.22 \pm 0.114$ & 3.86 & $*$ \\
\hline & 120 & $0.46 \pm 0.118$ & 7.80 & $* *$ & $0.27 \pm 0.094$ & 5.74 & ** \\
\hline & 144 & $-0.12 \pm 0.235$ & 1.02 & ns & $-0.09 \pm 0.232$ & 0.78 & ns \\
\hline \multirow{6}{*}{$30^{3}$} & 24 & $0.77 \pm 0.225$ & 6.84 & $* *$ & $0.20 \pm 0.270$ & 4.65 & ** \\
\hline & 48 & $0.20 \pm 0.270$ & 1.48 & ns & $0.28 \pm 0.354$ & 1.58 & ns \\
\hline & 72 & $0.55 \pm 0.114$ & 9.65 & $* * *$ & $0.44 \pm 0.150$ & 5.87 & ** \\
\hline & 96 & $-0.17 \pm 0.200$ & 1.70 & ns & $-0.13 \pm 0.175$ & 1.49 & ns \\
\hline & 120 & $0.20 \pm 0.178$ & 2.25 & ns & $0.20 \pm 0.161$ & 2.48 & ns \\
\hline & 144 & $0.39 \pm 0.192$ & 4.06 & $*$ & $0.42 \pm 0.298$ & 2.82 & $*$ \\
\hline
\end{tabular}

${ }^{1}=$ inoculated at $75 \mathrm{CFU} / \mathrm{ml}^{2}{ }^{2}=$ inoculated at $72 \mathrm{CFU} / \mathrm{ml},{ }^{3}=$ inoculated at $67 \mathrm{CFU} / \mathrm{ml}$

$\mathrm{d}=$ mean difference; $\mathrm{sd}=$ standard deviation of difference; $t$ = value of paired $t$-test criterion; $\mathrm{P}=$ significance; ns $=$ non-significant $(P>0.05) ; *=P \leq 0.05 ; * *=P \leq 0.01 ; * * * P \leq 0.001$.

counts of B. cereus were from 7.30 to $7.78 \log \mathrm{CFU} / \mathrm{ml}$. The statistical significance of differences between samples with (Z10-Z1000) and without zearalenon (Z0) have also not been unequivocally demonstrated even the most significant influences $(P<0.001$ and $P<0.01$ ) were observed after 96 hours of incubation at $22^{\circ} \mathrm{C}$ and after 72 hours at $30^{\circ} \mathrm{C}$ (Tab. I).

\section{Staphylococcus aureus}

The growth curves of $S$. aureus are shown in Fig. 4 to 6. In general, we can state, that ZEA didn't have significant effect on growth of $S$. aureus under the conditions described above. As expected $S$. aureus after initial inoculation of $86 \mathrm{CFU} / \mathrm{ml}$ maintained at $30^{\circ} \mathrm{C}$ showed similar growth parameters and reached similar final values as at temperature $22^{\circ} \mathrm{C}$ regardless of ZEA presence. The maximum count of S. aureus after $144 \mathrm{~h}$ of incubation at $30^{\circ} \mathrm{C}$ ranged between 9.08 (Z250) and 9.79 (C) log CFU/ml. The similar results have been achieved for the samples with initial concentration $142 \mathrm{CFU} / \mathrm{ml}$. The statistical significance of differences between samples with (Z10-Z1000) and without zearalenon (Z0) have also not been again unequivocally demonstrated. The most significant influences $(P<0.001)$ were observed after 120 hours of incubation at $22^{\circ} \mathrm{C}$ and after 72 hours at $30^{\circ} \mathrm{C}$ (Tab. II).

\section{Pseudomonas fluorescens}

The growth curves of $P$. fluorescens for both temperatures are shown in Fig. 7 and 8. The growth of $P$. fluorescence at $6.5^{\circ} \mathrm{C}$, was slower compared to growth at $22^{\circ} \mathrm{C}$ resulting in the highest count of $7.88 \log \mathrm{CFU} / \mathrm{ml}$ in $\mathrm{C}$ after $144 \mathrm{~h}$ of incubation. The growth curves of $P$. fluorescence at $22{ }^{\circ} \mathrm{C}$ were complete with rapid growth during first $24 \mathrm{~h}$ and stationary phase during the remaining part of the experiment. The final counts of bacteria at the end of incubations were similar and no effect of ZEA on growth of P. fluorescence was observed. The statistical significance of differences between samples with (Z10-Z1000) and without zearalenon (Z0) has not been also in this case unequivocally demonstrated. The most significant influences $(P<0.001)$ were observed after 48 hours of incubation at $22^{\circ} \mathrm{C}$ (Tab. III).

\section{DISCUSSION}

As mentioned in our previous study (Hanuš et al., 2018) the concentrations of ZEA used in this study reflected concentrations of ZEA found in milk (Z10) or maximum levels in foodstuffs (Z100 and Z250) or their multiples (Z500 and Z1000). 


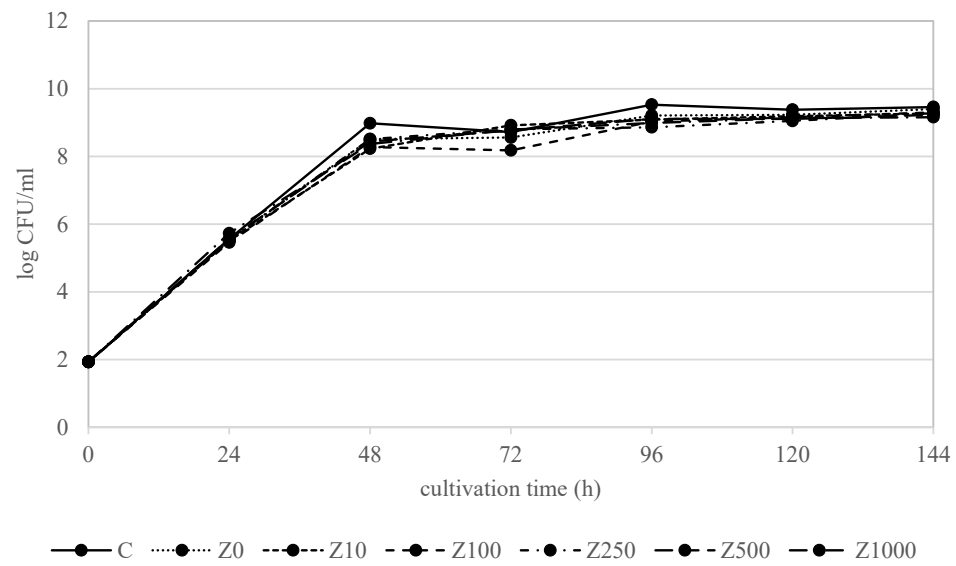

4: Growth curves of Staphylococcus aureus (inoculated at $86 \mathrm{CFU} / \mathrm{ml}$ ) at different zearalenone concentration at $22^{\circ} \mathrm{C}$

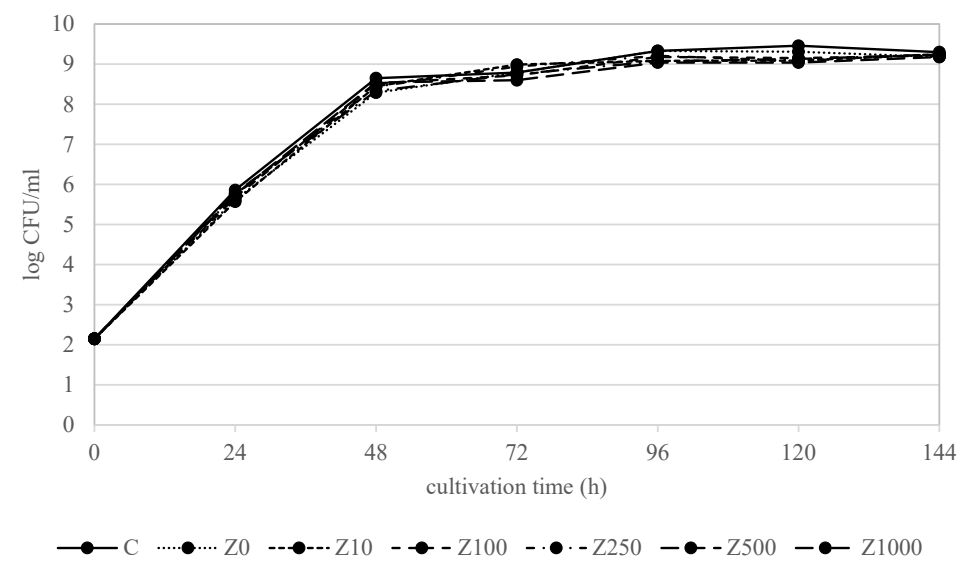

5: Growth curves of Staphylococcus aureus (inoculated at $142 \mathrm{CFU} / \mathrm{ml}$ ) at different zearalenone concentration at $22{ }^{\circ} \mathrm{C}$

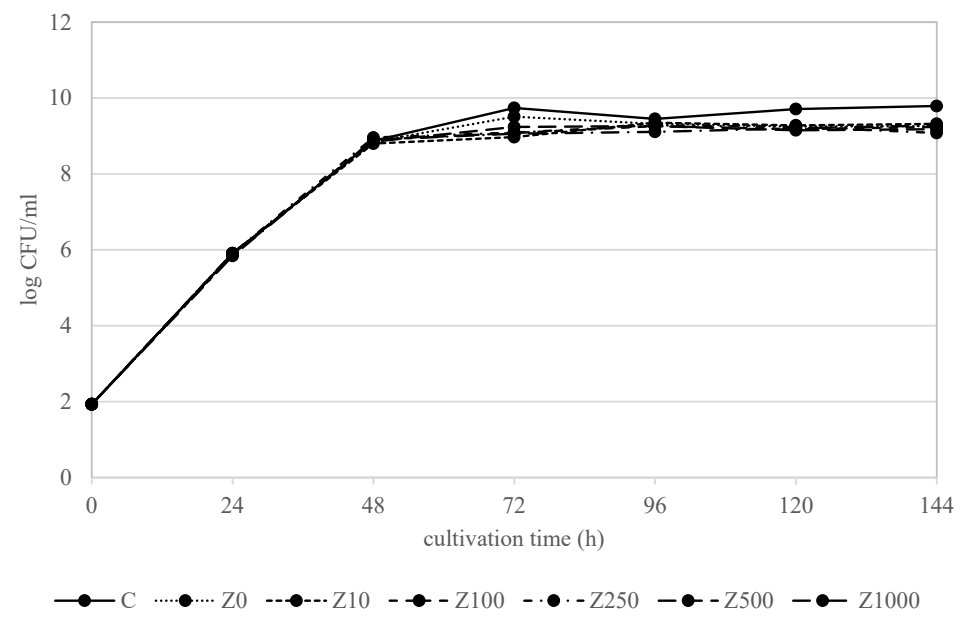

6: Growth curves of Staphylococcus aureus (inoculated at $86 \mathrm{CFU} / \mathrm{ml}$ ) at different zearalenone concentration at $30^{\circ} \mathrm{C}$ 
II: Results of differences and their significance between selected segments of the growth curves of Staphylococcus aureus without and with zearalenone addition $(n=5)$

\begin{tabular}{|c|c|c|c|c|c|c|c|}
\hline $\begin{array}{l}\text { Cultivation temp. } \\
\left({ }^{\circ} \mathrm{C}\right)\end{array}$ & $\begin{array}{l}\text { Cultivation time } \\
\text { (h) }\end{array}$ & $d \pm s d$ & $t$ & $\mathrm{P}$ & $d \pm s d(\log )$ & $t$ & $\mathrm{P}$ \\
\hline \multirow{6}{*}{$22^{1}$} & 24 & $-0.51 \pm 0.963$ & 1.06 & ns & $-0.05 \pm 0.102$ & 0.98 & ns \\
\hline & 48 & $0.87 \pm 0.613$ & 2.84 & $*$ & $0.14 \pm 0.114$ & 2.46 & ns \\
\hline & 72 & $-2.00 \pm 2.493$ & 1.60 & ns & $-0.13 \pm 0.292$ & 0.89 & ns \\
\hline & 96 & $0.57 \pm 0.223$ & 5.11 & $* *$ & $0.19 \pm 0.099$ & 3.84 & $*$ \\
\hline & 120 & $0.36 \pm 0.164$ & 4.39 & $*$ & $0.10 \pm 0.053$ & 3.77 & * \\
\hline & 144 & $0.72 \pm 0.215$ & 6.70 & $* *$ & $0.15 \pm 0.054$ & 5.56 & $* *$ \\
\hline \multirow{6}{*}{$22^{2}$} & 24 & $-1.00 \pm 0.951$ & 2.10 & ns & $-0.09 \pm 0.086$ & 2.09 & ns \\
\hline & 48 & $-0.94 \pm 0.512$ & 3.67 & $*$ & $-0.17 \pm 0.083$ & 4.10 & $*$ \\
\hline & 72 & $-0.52 \pm 2.490$ & 0.42 & ns & $-0.01 \pm 0.162$ & 0.12 & ns \\
\hline & 96 & $0.84 \pm 0.218$ & 7.71 & $* *$ & $0.21 \pm 0.074$ & 5.68 & $* *$ \\
\hline & 120 & $0.79 \pm 0.127$ & 12.44 & $* * *$ & $0.21 \pm 0.043$ & 9.77 & $* * *$ \\
\hline & 144 & $-0.17 \pm 0.099$ & 3.43 & $*$ & $-0.04 \pm 0.029$ & 2.76 & ns \\
\hline \multirow{6}{*}{$30^{3}$} & 24 & $0.05 \pm 0.604$ & 1.66 & ns & $0.02 \pm 0.034$ & 1.18 & ns \\
\hline & 48 & $-0.65 \pm 1.048$ & 1.24 & ns & $-0.03 \pm 0.060$ & 1.00 & ns \\
\hline & 72 & $2.00 \pm 0.292$ & 13.70 & $* * *$ & $0.42 \pm 0.097$ & 8.66 & *** \\
\hline & 96 & $0.26 \pm 0.346$ & 1.50 & ns & $0.07 \pm 0.088$ & 1.59 & ns \\
\hline & 120 & $0.16 \pm 0.196$ & 1.63 & ns & $0.04 \pm 0.051$ & 1.57 & ns \\
\hline & 144 & $0.13 \pm 0.350$ & 0.74 & ns & $0.04 \pm 0.094$ & 0.85 & ns \\
\hline
\end{tabular}

${ }^{1}=$ inoculated at $86 \mathrm{CFU} / \mathrm{ml},{ }^{2}=$ inoculated at $142 \mathrm{CFU} / \mathrm{ml},{ }^{3}=$ inoculated at $86 \mathrm{CFU} / \mathrm{ml}$

$\mathrm{d}=$ mean difference; $\mathrm{sd}=$ standard deviation of difference; $t=$ value of paired $t$-test criterion; $\mathrm{P}=$ significance; $n s=$ nonsignificant $(P>0.05) ;{ }^{*}=P \leq 0.05 ; * *=P \leq 0.01 ; * * *=P \leq 0.001$

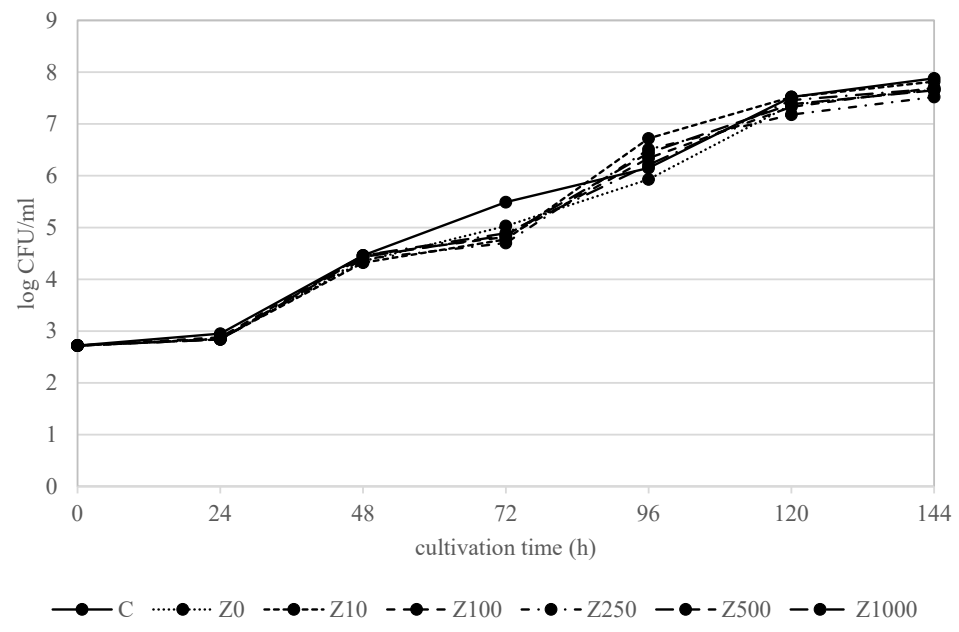

7: Growth curves of Pseudomonas fluorescens $Z B \quad 66$ and CCM 2826 at different zearalenone concentration (Z) at $6.5^{\circ} \mathrm{C}$ (average of $4 \log \mathrm{CFU} / \mathrm{ml}$ ) 


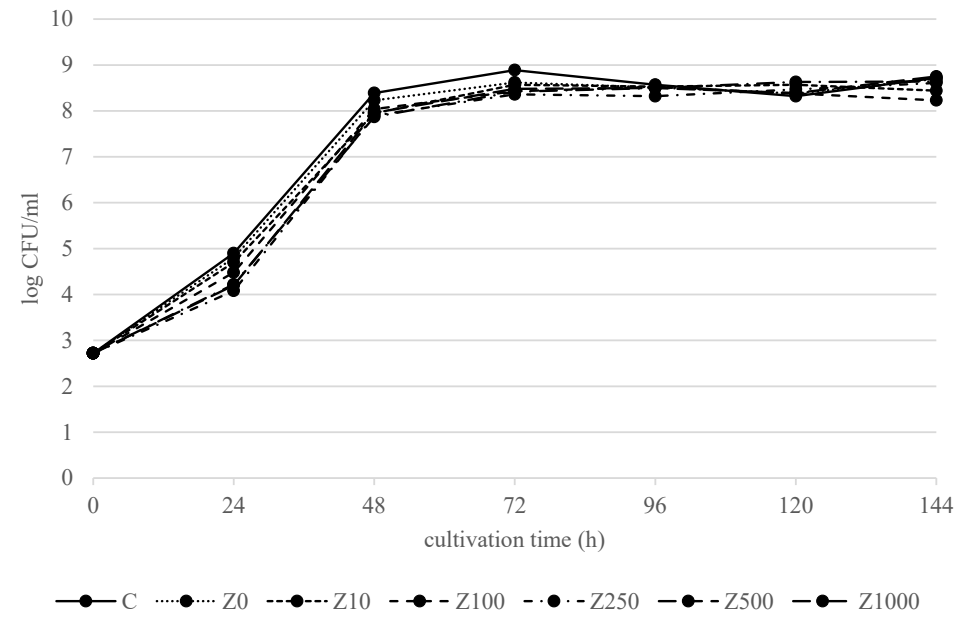

8: Growth curves of Pseudomonas fluorescens $Z B 66$ and CCM 2826 at different zearalenone concentration $(Z)$ at $22^{\circ} \mathrm{C}$

III: Results of differences and their significance between selected segments of the growth curves of Pseudomonas fluorescens ZB 66 and CCM 2826 without and with zearalenone addition $(n=5)$

\begin{tabular}{cccccccc}
\hline $\begin{array}{c}\text { Cultivation temp. } \\
\left({ }^{\circ} \mathrm{C}\right)\end{array}$ & $\begin{array}{c}\text { Cultivation time } \\
(\mathrm{h})\end{array}$ & $\mathrm{d} \pm \mathrm{sd}$ & $t$ & $\mathrm{P}$ & $\mathrm{d} \pm \mathrm{sd}(\mathrm{log})$ & $t$ & $\mathrm{P}$ \\
\hline & 24 & $-0.03 \pm 0.290$ & 0.21 & $\mathrm{~ns}$ & $0.00 \pm 0.017$ & 0.00 & $\mathrm{~ns}$ \\
& 48 & $-0.35 \pm 0.334$ & 2.10 & $\mathrm{~ns}$ & $-0.06 \pm 0.059$ & 2.03 & $\mathrm{~ns}$ \\
& 72 & $0.41 \pm 0.107$ & 7.66 & $* *$ & $0.22 \pm 0.074$ & 5.95 & $* *$ \\
\hline \multirow{2}{*}{6.5} & 96 & $-2.16 \pm 1.391$ & 3.11 & $*$ & $-0.51 \pm 0.191$ & 5.34 & $* *$ \\
& 120 & $-0.09 \pm 0.689$ & 0.26 & $\mathrm{~ns}$ & $0.00 \pm 0.131$ & 0.00 & $\mathrm{~ns}$ \\
& 144 & $-0.23 \pm 1.181$ & 0.39 & $\mathrm{~ns}$ & $-0.01 \pm 0.108$ & 0.19 & $\mathrm{~ns}$ \\
\hline & 24 & $3.79 \pm 1.571$ & 4.82 & $* *$ & $0.46 \pm 0.250$ & 3.68 & $*$ \\
& 48 & $0.80 \pm 0.133$ & 12.03 & $* * *$ & $0.29 \pm 0.065$ & 8.92 & $* * *$ \\
& 72 & $1.32 \pm 0.535$ & 4.93 & $* *$ & $0.17 \pm 0.079$ & 4.30 & $*$ \\
& 96 & $0.19 \pm 0.542$ & 0.70 & $\mathrm{~ns}$ & $0.04 \pm 0.087$ & 0.92 & $\mathrm{~ns}$ \\
& 120 & $-0.78 \pm 0.826$ & 1.89 & $\mathrm{~ns}$ & $-0.11 \pm 0.110$ & 2.00 & $\mathrm{~ns}$ \\
& 144 & $1.35 \pm 1.511$ & 1.79 & $\mathrm{~ns}$ & $0.17 \pm 0.203$ & 1.67 & $\mathrm{~ns}$ \\
\hline
\end{tabular}

$\mathrm{d}=$ mean difference; $\mathrm{sd}=$ standard deviation of difference; $t=$ value of paired $t$-test criterion; $\mathrm{P}=$ significance; $\mathrm{ns}=$ nonsignificant $(P>0.05) ;^{*}=P \leq 0.05 ;{ }^{* *}=P \leq 0.01 ;{ }^{* * *}=P \leq 0.001$

\section{Growth of Bacteria}

Bacillus cereus is a bacterium which can/ may occur in raw milk (Vyletělová et al., 2002). $B$. cereus grows at temperature range from 4 to $50^{\circ} \mathrm{C}$ and the optimum for growing is from 25 to $37^{\circ} \mathrm{C}$ (Bhunia, 2008). Maximal growth $(100 \%)$ of B. cereus was observed at $30^{\circ} \mathrm{C}$ for 48 hours in raw milk (Montanhini et al. 2013) and multiplication of B. cereus in pasteurized milk at 8,15 and $22^{\circ} \mathrm{C}$ (Necidová et al., 2014). Our results confirmed the growth and multiplication at $22^{\circ} \mathrm{C}$ and also at $30^{\circ} \mathrm{C}$ in accordance with above mentioned studies. On the other hand, faster growth of $B$. cereus in pasteurized milk at $30{ }^{\circ} \mathrm{C}$ with maximum reached after 8 hours of incubation described Wong et al, (1988). The final counts of $P$. fluorescens after $144 \mathrm{~h}$ incubation at $6.5^{\circ} \mathrm{C}$ and after $48 \mathrm{~h}$ at $22^{\circ} \mathrm{C}$ were lower than that reported by Colantuono et al. (2020) for $4{ }^{\circ} \mathrm{C}$ and $25^{\circ} \mathrm{C}$ but close to values found by Miguel et al. (2019) for incubations at $7^{\circ} \mathrm{C}$ for 6 days. Discrepancies in the growth parameters of bacteria can be explained by a different composition of culture medium or incubation conditions.

\section{Effect of Zearalenone on Milk Pathogens}

Generally, the interactions between mycotoxins and bacteria are studied mainly from two reasons - for the ability of some microorganisms to detoxify mycotoxins and for the ability of mycotoxins to change, either quantitatively or qualitatively, composition of the intestinal microbiota when animals are exposed to dietary mycotoxins. Concerning to 
ZEA-degrading abilities, several species of Lactobacillus, Pseudomonas, Bacillus, Lysinibacillus, Rhodoccous or Streptomyces have been identified to degrade ZEA (Venkatesh, Keller, 2019; Cheng et al., 2016). On the other hand, information about the effect of ZEA on viability of microorganisms are scarce and inconsistent. In the present study mild negative effect of ZEA on growth of studied bacteria was observed but it differed in dependence on the incubation time and temperature and the type of bacteria (see Tabs. I, II, III). This is in agreement with the results of our previous study (Hanuš et al., 2018) but in discrepancy with Vyletělová et al. (2005) who described no significant difference in the growth of yoghurt culture YC-180-YO-Flex containing Streptococcus thermophilus, Lactobacillus delbrueckii subsp. lactis and L. delbrueckii subsp. bulgaricus strains when incubated with graded concentration of ZEA. This discrepancy can be explained by different mechanisms of ZEA toxicity as affected by different doses and cell types because high doses of ZEA can cause cell death, while low doses can stimulate the proliferation of cells (Zheng et al., 2018). Concerning to cell type, ZEA may exert the stimulating effects in the cells from tissues with estrogen receptors but the cytotoxic effects in the cells from the tissues which have no estrogen receptors (Zheng et al., 2018). Furthermore, length of exposure may also play a role in the ZEA effects on cells because Piotrowska et al. (2014) noted a detrimental effect of a long-term exposure to low levels of ZEA on aerobic mesophilic bacteria in the pig's colon while Wang et al. (2018) found no effect of short-term ZEA exposure on the predominant bacteria of the jejunum. According to Zhang et al. (2020) ZEA treatment slightly increased the intestinal microbiota diversity but significantly decreased the $\beta$ diversity. Concerning to microbiota structure, exposure to ZEA caused decrease in the abundance of Firmicutes and increase in the abundace of Bacteroidetes. Further studies are needed to clarify factors influencing the effect of ZEA on growth and viability of microorganisms.

\section{CONCLUSION}

The results mentioned above didn't fully correspond to the effect of ZEA on milk cultures. Selected microorganisms of $B$. cereus, S. aureus and P. fluorescens were only sporadically reduced in their growth by the mycotoxin ZEA in dependence on the incubation time and temperature, the type of bacteria and initial inoculation counts. The susceptibility of selected natural and pathogenic dairy microorganisms to the inhibitory effect of ZEA has thus been proven to a small extent.

\section{Acknowledgements}

This research was supported by the Ministry of Agriculture of the Czech Republic, Project No. MZe RO1420 and by the Ministry of Education, Youth and Sports of the Czech Republic, Project No. MSM 6215712402.

\section{REFERENCES}

ANDERSSON, A., RONNER, U. and GRANUM, P. E. 1995. What problems does the food industry have with the spore-forming Bacillus cereus and Clostridium perfringens? International Journal of Food Microbiology, 28(2): 145-155.

BECKER-AlgERI, T. A., CASTAGNARO, D., DE BORTOLI, K., DE SOUZA, C., DRUNKLER, D. A. and BADIALE-FURLONG, E. 2016. Mycotoxins in Bovine Milk and Dairy Products: A Review. Journal of Food Science, 81(3): R544-R552.

BHUNIA, A. K. 2008. Bacillus cereus and Bacillus anthracis. In: BHUNIA, A. K. (Ed.). Foodborne Microbial Pathogens. $1^{\text {st }}$ Edition. New York: Springer, pp. 135-148.

BOOR, K. J., WIEDMANN, M., MURPHY, S. and ALCAINE, S. 2017. A 100-Year Review: Microbiology and safety of milk handling. Journal of Dairy Science, 100(12): 9933-9951.

CHENG, J., FAN, Y. and ZHAO, L. 2016. Review on biological degradation of mycotoxins. Animal Nutrtion, 2(3): 127-133.

COLANTUONO, A., D'INCECCO, P., FORTINA, M. G., ROSI, V., RICCI, G. and PELLEGRINO, L. 2020. Milk substrates influence proteolytic activity of Pseudomonas fluorescens strains. Food Control, 111: 107063.

CZECH NORMALIZATION INSTITUTE. 1999. Microbiology offood and animal feeding stuffs - Horizontal method for the enumeration of coagulase-positive staphylococci (Staphylococcus aureus and other species) - Part 1: Technique using Baird-Parker agar medium [in Czech: Mikrobiologie potravin a krmiv - Horizontální metoda stanovení počtu koagulázopozitivních stafylokoků (Staphylococcus aureus a další druhy) - Část 1: Technika s použitím agarové půdy podle Baird-Parkera]. ČSN EN ISO 6888-1. Prague: Czech normalization institute. 
CZECH NORMALIZATION INSTITUTE. 2008. Microbiology of food and animal feeding stuffs - General requirements and guidance for microbiological examinations [in Czech: Mikrobiologie potravin a krmiv - Všeobecné požadavky a doporučení pro mikrobiologické zkoušení]. ČSN EN ISO 7218. Prague: Czech normalization institute.

CZECH NORMALIZATION INSTITUTE. 1995. Microbiology. General guidance for enumeration of Bacillus cereus. Colony count technique at $30^{\circ} \mathrm{C}$ [in Czech: Mikrobiologie. Všeobecné pokyny pro stanovení počtu Bacillus cereus. Technika počitání kolonií vykultivovaných při $\left.30^{\circ} \mathrm{C}\right]$. ČSN ISO 7932. Prague: Czech normalization institute.

CZECH NORMALIZATION INSTITUTE. 2005. Milk - Estimation of psychrotrophic microorganisms Colony-count technique at $21^{\circ} \mathrm{C}$ (Rapid method) [in Czech: Mléko - Stanovení počtu psychrotrofních mikroorganismů - Technika stanovení počtu kolonií při $21^{\circ} \mathrm{C}$ (Rychlá metoda)]. ČSN ISO 8552. Prague: Czech normalization institute.

FLORES-FLORES, M. E., LIZARRAGA, E., LÓPEZ DE CERAIN, A. and GONZÁLEZ-PEÑAS, E. 2015. Presence of mycotoxins in animal milk: A review. Food Control, 53: 163-176.

HANUŠ, O., JANU゚, L., SCHUSTER, J., KUČERA, J., VYLETĚLOVÁ, M. and GENČUROVÁ, V. 2011. Exploratory analysis of dynamics of frequency distribution of raw cow milk quality indicators in the Czech Republic. Acta Universitatis Agriculturae et Silviculturae Mendelianae Brunensis, 59(1): 83-100.

HANUŠ, O., KŘÍŽOVÁ, L., HAJŠLOVÁ, J., LOJZA, J., KLIMEŠOVÁ, M., JANŮ, L., ROUBAL, P., KOPECKÝ, J. and JEDELSKÁ, R. 2018. Effect of increasing zearalenone levels on the coagulation properties of milk and the viability of yogurt bacteria. Czech Journal of Food Sciences, 36(4): 277-283.

JAMALI, H., PAYDAR, M., RADMEHR, B., ISMAIL, S. and DADRASNIA, A. 2015. Prevalence and antimicrobial resistance of Staphylococcus aureus isolated from raw milk and dairy products. Food Control, 54: 383-388.

JØRGENSEN, H., MØRK, T., HØGASEN, H. and RØRVIK, L. 2005. Enterotoxigenic Staphylococcus aureus in bulk milk in Norway. Journal of Applied Microbiology, 99(1): 158-166.

KUMARI, S. and SARKAR, P. K. 2016. Bacillus cereus hazard and control in industrial dairy processing environment. Review. Food Control, 69: 20-29.

MEHLI, L., HOEL, S., THOMASSEN, G. and JAKOBSEN, A. 2017. The prevalence, genetic diversity and antibiotic resistance of Staphylococcus aureus in milk, whey, and cheese from artisan farm dairies. International Dairy Journal, 65: 20-27.

MIGUEL, E. M., SOBRAL, D., MOREIRA, G. D. M., COSTA, R. G. B., TEODORO, V. A. M. and DE CARVALHO, A. F. 2019. Multiplication of Pseudomonas fluorescens in refrigeration temperatures and its proteolytic potential. Journal of Candido Tostes Dairy Institute, 74(2): 96-107.

MONTANHINI, M. T. M., MONTAHINI, R. N., PINTO, J. P. N. and BERSOT, L. S. 2013. Effect of temperature on the lipolytic and proteolytic activity of Bacillus cereus isolated from dairy products. International Food Research Journal, 20(3): 1417-1420.

NECIDOVÁ, L., BURSOVÁ, Š., SKOČKOVÁ, A., JANŠTOVÁ, B., PRACHAŘOVÁ, P., ŠEVČÍKOVÁ, Ž. and JANŠTOVÁ, B. 2014. Growth and enterotoxin production of Bacillus cereus in cow, goat, and sheep milk. Acta Veterinaria Brunensis, 83: S3-S8.

NORIEGA, L., GUEIMONDE, M., ALONSO, L. and DE LOS REYES-GAVILÁN, C. G. 2003. Inhibition of Bacillus cereus growth in carbonated fermented bifidus milk. Food Microbiology, 20(5): 519-526.

PÁČOVÁ, Z., ŠVEC, P., STENFORS, L. P., VYLETĚLOVÁ, M. and SEDLÁČEK, I. 2003. Isolation of the psychrotolerant species Bacillus weihenstephanensis from raw cow's milk. Czech Journal of Animal Science, 48(2): 93-96.

PIOTROWSKA, M., ŚLIŻEWSKA, K., NOWAK, A., ZIELONKA, Ł., ŹAKOWSKA, Z., GAJĘCKA, M. and GAJECCKI, M. 2014. The effect of experimental Fusarium mycotoxicosis on microbiota diversity in porcine ascending colon contents. Toxins, 6(7): 2064-2081.

ROSSIGNOL, G., SPERANDIO, D., GUERILLON, J., DUCLAIROIR POC, C., SOUM-SOUTERA, E., ORANGE, N., FEUILLOLEY, M. G. J. and MERIEAU, A. 2009. Phenotypic variation in the Pseudomonas fluorescens clinical strain MFN1032. Research in Microbiology, 160(5): 337-344.

TINYIRO, S. E., WOKADALA, C., XU, D. and YAO, W. 2011. Adsorption and degradation of zearalenone by Bacillus strains. Folia Microbiologica, 56: 321-327.

VALÍK, L'., AČAI, P. and MEDVEĎOVÁ, A. 2018. Application of competitive models in predicting the simultaneous growth of Staphylococcus aureus and lactic acid bacteria in milk. Food Control, 87(2): 145-152.

VENKATESH, N. and KELLER, N. P. 2019. Mycotoxins in conversation with bacteria and fungi. Frontiers in Microbiology, 10: 403.

VYLETĚLOVÁ, M. and HANUŠ, O. 2000. Effects of contamination by Pseudomonas fluorescens on principal components and technological parameters of pasteurized milk during storage. Czech Journal of Food Sciences, 18(6): 224-234. 
VYLETĚLOVÁ, M., HANUŠ, O., URBANOVÁ, E. and KOPUNECZ, P. 2000. The occurrence and identification of psychrotrophic bacteria with proteolytic and lipolytic activity in bulk milk samples at storage in primary production conditions. Czech Journal of Animal Science, 45(8): 373-383.

VYLETĚLOVÁ, M., JANŮ, L. and HANUŠ, O. 2005. Influence of mycotoxin zearalenone on growth of bacteria genus Streptococcus and Lactobacillus. In: Eighth Symposium on lactic acid bacteria: Genetics, metabolism and applications. 28 August-1 September, Egmond aan Zee, The Netherlands.

VYLETĚLOVÁ, M., ŠVEC, P., PÁČOVÁ, Z., SEDLÁČEK, I. and ROUBAL, P. 2002. Occurrence of Bacillus cereus and Bacillus licheniformis strains in the course of UHT milk production. Czech Journal of Animal Science, 47(5): 200-205.

WANG, X., YU, H., SHAN, A., JIN, Y., FANG, H., ZHAO, Y., SHEN, J., ZHOU, C., ZHOU, Y. and FU, Y. 2018. Toxic effects of Zearalenone on intestinal microflora and intestinal mucosal immunity in mice. Food and Agricultural Immunology, 29(1): 1002-1011.

WONG, H. C., CHEN, Y. L. and CHEN, C. L. F. 1988. Growth, germination and toxigenic activity of Bacillus cereus in milk products. Journal of Food Protection, 51(9): 707-710.

ZHANG, W., ZHANG, S., WANG, J., SHAN, A. and XU, L. 2020. Changes in intestinal barrier functions and gut microbiota in rats exposed to zearalenone. Ecotoxicology and Environmental Safety, 204(11): 111072.

ZHENG, W., WANG, B., LI, X., WANG, T., ZOU, H., GU, J., YUAN, Y., LIU, X., BAI, J., BIAN, J. and LIU, Z. 2018. Zearalenone promotes cell proliferation or causes cell death? Review. Toxins, 10(5): 184.

Ludmila Kř́žová: krizoval@vfu.cz

Marcela Klimešová: marcela.vyletelova@seznam.cz

Oto Hanuš: hanus.oto@seznam.cz

Irena Němečková: nemeckova@milcom-as.cz

Petr Roubal: roubal@milcom-as.cz

Jana Tšponová: tsponovaj@vfu.cz

Miroslav Skřivánek: farmavs@seznam.cz

Ludmila Nejeschlebová: ludmila.mnejeschlebova@seznam.cz

Radoslava Jedelská: Radka.Jedelska@seznam.cz 